\title{
Genetic diversity analysis of Capsicum spp germplasm bank accessions based on $\alpha / \beta$-esterase polymorphism
}

\author{
E.R. Monteiro ${ }^{1}$, A.R. Bronzato ${ }^{1}$, G.R. Orasmo ${ }^{2}$, A.C.A. Lopes ${ }^{2}$, \\ R.L.F. Gomes ${ }^{3}$, C.A. Mangolin ${ }^{1}$ and M.F.P.S. Machado ${ }^{1}$ \\ ${ }^{1}$ Departamento de Biologia Celular e Genética, \\ Universidade Estadual de Maringá, Maringá, PR, Brasil \\ ${ }^{2}$ Departamento de Biologia, Universidade Federal do Piauí, Teresina, PI, Brasil \\ ${ }^{3}$ Departamento de Agronomia, Universidade Federal do Piauí, \\ Teresina, PI, Brasil \\ Corresponding author: M.F.P.S. Machado \\ E-mail:mfpsmachado@uem.br \\ Genet. Mol. Res. 12 (2): 1155-1167 (2013) \\ Received May 22, 2012 \\ Accepted November 19, 2012 \\ Published April 12, 2013 \\ DOI http://dx.doi.org/10.4238/2013.April.12.2
}

\begin{abstract}
Genetic diversity and structure were analyzed in 10 accessions belonging to Banco Ativo de Germoplasma de Capsicum located at Federal University of Piauí in northwestern Brazil that receives pepper samples grown in community gardens in various regions and Brazilian states. Selections were made from seeds of $C$. chinense (4 accessions), C. annuum (5 accessions), and C. baccatum (1 accession). Samples consisting of leaves were collected from 4-10 plants of each accession (a total of 85 plants). Native polyacrylamide gel electrophoresis was used to identify $\alpha$ - and $\beta$-esterase polymorphisms. Polymorphism was clearly detected in 5 loci. Sixteen alleles were found at $5 \alpha / \beta$-esterase loci of the three Capsicum species. In the $C$. chinense samples, the highest $H_{\mathrm{O}}$ and $H_{\mathrm{E}}$ values were 0.3625 and 0.4395 , respectively, whereas in C. annuum samples, $H_{\mathrm{O}}$ and $H_{\mathrm{E}}$ values were 0.2980 and 0.3310 , respectively; the estimated $H_{\mathrm{O}}$ and $H_{\mathrm{E}}$ values in $C$. chinense samples were higher than those detected in $C$. annuum samples. A deficit of
\end{abstract}


homozygous individuals was found in $C$. chinense $\left(F_{\text {IS }}=-0.6978\right)$ and C. annuum $\left(F_{\mathrm{IS}}=0.7750\right)$. Genetic differentiation between $C$. chinense and $C$. annuum at these loci was high $\left(F_{\mathrm{ST}}=0.1867\right)$ indicating that C. chinense and C. annuum are genetically structured species for $\alpha / \beta$ esterase isozymes. The esterase analysis showed high genetic diversity among the $C$. chinense and $C$. annuum samples and very high genetic differentiation $\left(F_{\mathrm{ST}}=0.6321\right)$ among the $C$. chinense and $C$. annuum samples and the $C$. baccatum accession.

Key words: Peppers; Capsicum spp; Esterase; Isozymes; Genetic diversity

\section{INTRODUCTION}

Peppers of the genus Capsicum are economically important in several countries. Fruits of Capsicum species are preferentially consumed fresh in the human diet and used in the preparation of sauces and dry seasonings (Kirschbaum-Titze al., 2002). Some species of the genus have medicinal and ornamental applications as well (Pickersgill, 1991; Bosland and Votava, 2000). Polymorphism for plant growth, flower color, and fruit form and color is large in Capsicum species (see Mosconeet al., 2007). Particularly in the cultivated peppers, fruit traits are highly variable within species owing to human selection (Pickersgill, 1988).

The Capsicum genus has 31 related species, among which C. annuum L., C. baccatum L., C. chinense Jacq., C. frutescens L., and C. pubescens Ruiz \& Pav. are domesticated (Pickersgill, 1997; Moscone et al., 2007). C. annuum has high nutritional content, especially vitamins, and is the most cultivated species, represented by sweet pepper ("pimenta doce"), bell pepper ("pimentão"), and pimiento ("pimentão vermelho"). C. baccatum is represented by the peppers "dedo-de-moça" and "chapéu-de-frade", which are the most cultivated varieties in Brazil (Reifschneider, 2000). Most varieties of $C$. chinense are traditionally cultivated in northwestern Brazil, in which they are known as "pimenta-de-cheiro" and "pimenta-debode". The $C$. frutescens species known as "malagueta" is a highly pungent cultivar enjoyed in southwestern Brazil. C. pubescens is widely cultivated from Mexico to Peru, where it is grown in highlands in small family plots. It is grown on very limited acreage throughout the rest of the world (Bosland and Votava, 2000).

C. annuum, C. chinense, and C. frutescens have been considered closely related taxa according to karyotype features; these species are included in the C. annuиm complex, in which poorly developed crossing barriers and great similarities with respect to morphology, isozymes, and DNA sequence suggest that they could be conspecific (Pickersgill, 1988, 1991; Park et al., 2000; Walsh and Hoot, 2001). In Brazil, various pepper species and their cultivars have been maintained in the germplasm collections of research institutes and universities. These collections have originated from traditional cultivars collected in various states and regions of Brazil among which the same genotype might be cultivated under different names, or different genotypes might be identified by the same name. The Federal University of Piauí in northwestern Brazil has a seed bank of peppers of the Capsicum genus [Banco Ativo de Germoplasma de Capsicum (BAGC)] that receives pepper samples that are often grown in community gardens in various regions and Brazilian states, mainly those in the northwest. The 
main aim of the BAGC, which is located at the Federal University of Piauí, is to preserve and maintain the genetic diversity of Capsicum pepper accessions.

The seed bank collections of Capsicum represent quantitatively only a small fraction of the global biodiversity, but they are undoubtedly important as stocks of genetic diversity, and they represent a source of alleles for the genetic improvement of crops. Most samples of peppers that are deposited in the seed bank are identified only with the place and date of collection and the popular name or scientific name; many samples bear no additional specifications to ensure that an organization had approved proposals for the cultivation and breeding of the species. Therefore, the genetic characterization of the samples maintained in BAGC is important to confirm their genetic relationship. Genetic characterization of the samples allows the introduction of the accessions into an environment and guides the development of future cultural practices. The polymorphisms for morphological and agronomic traits of plant and fruit are extraordinarily important and frequently the main aim of selection programs (Monteiro et al., 2010). Therefore, molecular polymorphism is valuable information for the genetic characterization of Capsicum pepper accessions maintained at BAGC.

Protein electrophoresis studies (McLeod et al., 1983; Loaiza-Figueroa et al., 1989) in addition to DNA sequence analyses (Walsh and Hoot, 2001) and studies of restriction fragment length polymorphisms, polymerase chain reaction-amplified fragment length polymorphisms, randomly amplified polymorphic DNA, and polymorphic plastid DNA markers (Buso et al., 2001; Votava et al., 2005) have contributed to knowledge of the genetic diversity in the Capsicum genus and relationships among species. Polyacrylamide gel electrophoresis (PAGE) has been used to analyze $\alpha$ - and $\beta$-esterase genetic polymorphism in plants (Pereira et al., 2001; Carvalho et al., 2003; Orasmo et al., 2007; Frigo et al., 2009) and is also useful for analyses of the genetic diversity and structure of Capsicum accessions maintained at BAGC. Esterases are often found in multigene families (Robin et al., 1996), and a large number of esterase loci in plant tissues can be used simultaneously for the identification of genetic variation and polymorphism analyses. Esterase isozyme polymorphisms are co-dominant markers, which are useful for analyzing the genetic structure of plant populations. Thus, the goal of the current study was to use native PAGE to identify polymorphism in the $\alpha / \beta$-esterase loci of the Capsicum pepper genus and analyze the genetic diversity and structure of C. annuum, C. chinense, and $C$. baccatum samples. Knowing the differences among these samples is important for the conservation of various genotypes as well as for carrying out crosses of these species in genetic breeding programs. Our hypothesis was that the polymorphisms of the $\alpha / \beta$-esterase isozymes examined using a PAGE system represent adequate and promising markers with which to determine the differences, similarities, and identities of genotypes quickly.

\section{MATERIAL AND METHODS}

\section{Capsicum samples}

Seeds of 10 accessions were provided by Dr. Ângela C.A. Lopes (Federal University of Piauí, Brazil). The accessions belonged to BAGC. Selections were made from seeds of $C$. chinense (BAGC 06, BAGC 07, BAGC 23, and BAGC 24), C. annuum (BAGC 11, BAGC 36, BAGC 40, BAGC 59, and BAGC 67), and C. baccatum (BAGC 26; Table 1). The samples were collected in home gardens and community gardens and identified with the date and site 
of collection and the scientific and common names. The seeds of 10 plants per accession were germinated in 128-cell trays using commercial substrates and maintained in an acclimatized chamber. After germination, seedlings (with 4-6 leaves) were transferred to pots containing soil and substrate (1:1) and maintained at a house garden (Department of Agronomy, State University of Maringá, Brazil). Figure 1 illustrates some C. chinense, C. baccatum var. pendulum, C. annuиm var. annuиm, and C. annuиm var. glabriusculum plants used for electrophoresis analysis.

Table 1. Accessions belonging to Banco Ativo de Germoplasma de Capsicum (BAGC) for genetic diversity analysis.

\begin{tabular}{|c|c|c|c|}
\hline Accession identifier & Common name & Species and variety & Site of collection (City / State) \\
\hline BAGC 06 & Murici & C. chinense & Teresina / PI \\
\hline BAGC 07 & Peito de moça & C. chinense & Piripiri / PI \\
\hline BAGC 11 & Peito de moça & C. annuum var. glabriusculum & Teresina / PI \\
\hline BAGC 23 & Olho de peixe & C. chinense & Teresina / PI \\
\hline BAGC 24 & Dedo de moça & C. chinense & Recife / PE \\
\hline BAGC 26 & Unknown & C. baccatum var. pendulum & Teresina / PI \\
\hline BAGC 36 & Pimenta de mesa & C. annuum var. glabriusculum & Teresina / PI \\
\hline BAGC 40 & Mexicana longa & C. annuum var. annuum & Teresina / PI \\
\hline BAGC 59 & Unknown & C. annuum var. glabriusculum & São Luis / MA \\
\hline BAGC 67 & Unknown & C. annuum var. glabriusculum & Água Branca / PI \\
\hline
\end{tabular}

PI = Piauí; PE = Pernambuco; MA = Maranhão.
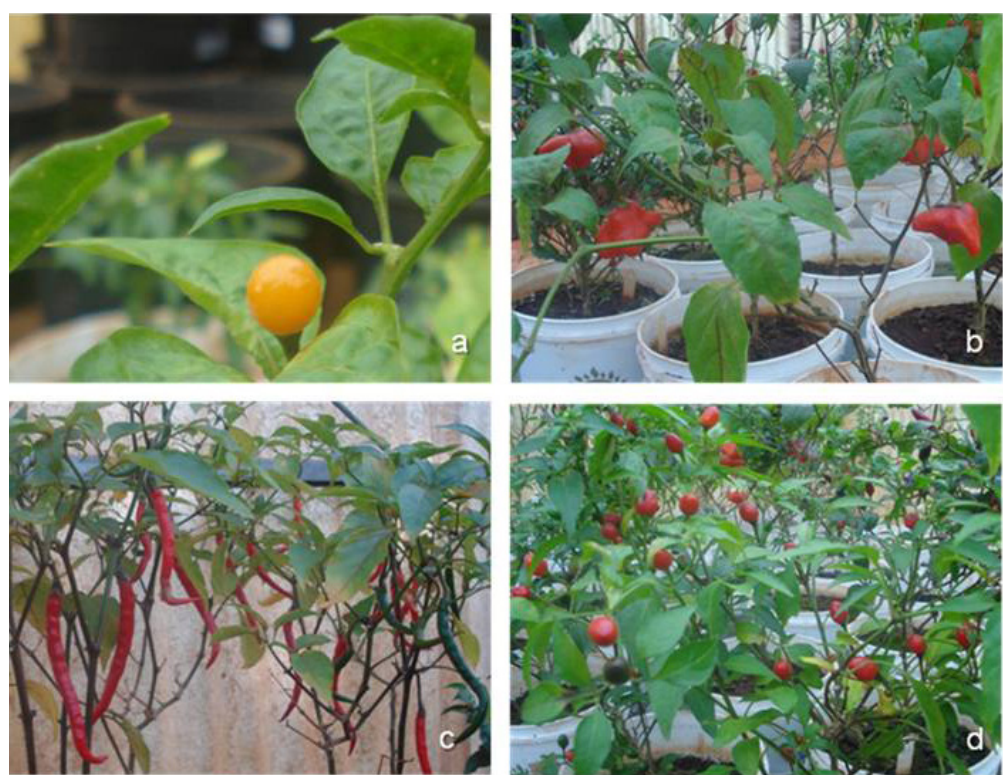

Figure 1. Plants of Capsicum chinense (a. BAGC 23), C. baccatum var. pendulum (b. BAGC 26), C. annuum var. annuит (c. BAGC 40), and C. annuиm var. glabriusculum (d. BAGC 36) used for electrophoresis analysis.

\section{Electrophoresis}

Samples consisting of leaves collected from 4-10 plants of each accession (a total of 85 plants) were evaluated using electrophoresis. Leaf fragments $(7 \mathrm{mg})$ were individually homog- 
enized with a glass rod in an Eppendorf microcentrifuge tube using a 70-mL extraction solution containing $1.0 \mathrm{M}$ phosphate buffer, $\mathrm{pH} 7.0$, with $5 \%$ polyvinylpyrrolidone- 40 (Sigma), $1.0 \mathrm{mM}$ ethylenediaminetetraacetic acid (Invitrogen), $0.5 \% \beta$-mercaptoethanol, and 10\% glycerol solution, and maintained in an ice chamber. After homogenization, the samples were centrifuged at 14,000 $\operatorname{rpm}(12,052 \mathrm{~g})$ for $30 \mathrm{~min}$ at $4^{\circ} \mathrm{C}$ in a Jouan MR23i, and the supernatant was used for each sample.

Polyacrylamide gels $(12 \%)$ were prepared using $0.375 \mathrm{M}$ Tris-HCl, pH 8.8 (Pereira et al., 2001). A 6.2-mL volume of acrylamide/bis-acrylamide solution [30 g acrylamide and $0.8 \mathrm{~g}$ bis-acrylamide (Invitrogen) dissolved in $100 \mathrm{~mL}$ double-distilled water], $4.0 \mathrm{~mL} 1.5 \mathrm{M}$ Tris-HCl, $\mathrm{pH}$ 8.0, $6.2 \mathrm{~mL}$ double-distilled water, $320 \mu \mathrm{L}$ ammonium persulfate $2 \%$ (Sigma), and $16 \mu \mathrm{L}$ tetramethylethylenediamine (Invitrogen) were used for the gel of separation. The stacking gel was prepared with $3.0 \mathrm{~mL}$ acrylamide/bis-acrylamide $(5 \mathrm{~g}$ acrylamide and $0.25 \mathrm{~g}$ bis-acrylamide dissolved in $50 \mathrm{~mL}$ double-distilled water), $3.0 \mathrm{~mL} 0.24 \mathrm{M}$ Tris- $\mathrm{HCl}, \mathrm{pH} 6.8$, $30 \mu \mathrm{L}$ double-distilled water, $250 \mu \mathrm{L}$ ammonium persulfate $(2 \%)$, and $3 \mu \mathrm{L}$ tetramethylethylenediamine. Electrophoresis was performed for $5 \mathrm{~h}$ at $4^{\circ} \mathrm{C}$ at a constant voltage of $200 \mathrm{~V}$. The running buffer was $0.125 \mathrm{M}$ Tris/0.0959 M glycine, $\mathrm{pH} 8.3$.

The $\alpha / \beta$-esterases were identified using staining techniques described by Pereira et al. (2001). Gels were soaked for $30 \mathrm{~min}$ in $50 \mathrm{~mL} 0.1 \mathrm{M}$ sodium phosphate, $\mathrm{pH}$ 6.2, at room temperature. Esterase activity was visualized by placing the gels in a staining solution prepared with $50 \mathrm{~mL}$ sodium phosphate solution, $40 \mathrm{mg} \beta$-naphthyl acetate, $40 \mathrm{mg} \alpha$-naphthyl acetate, $60 \mathrm{mg}$ Fast Blue RR salt, and $5 \mathrm{~mL}$ N-propanol for $1 \mathrm{~h}$. The staining solution was prepared using reagents, substrates, and dye (Sigma).

After being dried as described by Pereira et al. (2001), the polyacrylamide gels were kept at room temperature for $60 \mathrm{~min}$ in a mixture of $7.5 \%$ acetic acid and $10 \%$ glycerol embedded in 5\% gelatin. They were then placed between two sheets of wet cellophane paper, stretched on an embroidering hoop and left to dry for 24 to $48 \mathrm{~h}$.

\section{Data analysis}

Genetic variability in the Capsicum genus samples and in C. annuum and C. chinense was analyzed using the POPGENE 1.32 program (Yeh et al., 1999). The allele frequencies, percentage of polymorphic loci, chi-square test for deviation from Hardy-Weinberg equilibrium, observed and expected mean heterozygosity $\left(H_{\mathrm{O}}\right.$ and $\left.H_{\mathrm{E}}\right)$, mean number of alleles per locus, and effective number of alleles per polymorphic locus $\left(N_{\mathrm{E}}\right)$, were estimated for the esterase loci and 10 pepper accessions. The fixation index $\left(F_{\text {IS }}\right)$ and Wright's $(1965) F$-statistic values $\left(F_{\text {IT }}\right.$ and $\left.F_{\mathrm{ST}}\right)$ were also calculated for the esterase loci. The genetic identity (Nei, 1978) among Capsicum samples was calculated using the unweighted pair group method with arithmetic means.

\section{RESULTS}

Native PAGE analysis for esterase isozymes in the leaves of pepper plants from the Capsicum genus recorded using $\alpha$-naphthyl acetate and $\beta$-naphthyl acetate indicated several $\alpha / \beta$-esterases, but polymorphism was clearly detected in only 5 loci. The esterases produced from the Est-4 locus were observed as strongly stained bands (Figure 2), and only 2 alleles were detected at the Est-4 locus in the 85 pepper plants analyzed of $C$. annuum ( 5 accessions), C. chinense (4 accessions), and C. baccatum (1 accession) species. Three alleles each were 
detected at the Est-2, Est-3, and Est-5 loci, and 5 alleles for $\alpha / \beta$-esterases were detected at the Est-1 locus. A total of 16 alleles were found at the $5 \alpha / \beta$-esterase loci of the three Capsicum species. The less anodic $\alpha / \beta$-esterases exhibited coincident migration in the electrophoresis gels, and the electrophoresis phenotypes could not be clearly determined. Only the polymorphisms at the Est-1, Est-2, Est-3, Est-4, and Est-5 loci were analyzed, and allele frequencies were analyzed for these loci as well. Table 2 shows the number of alleles, $N_{\mathrm{E}}$, and mean $H_{\mathrm{O}}$ and $H_{\mathrm{E}}$ in each of the accessions from C. annuum, C. chinense, and C. baccatum.

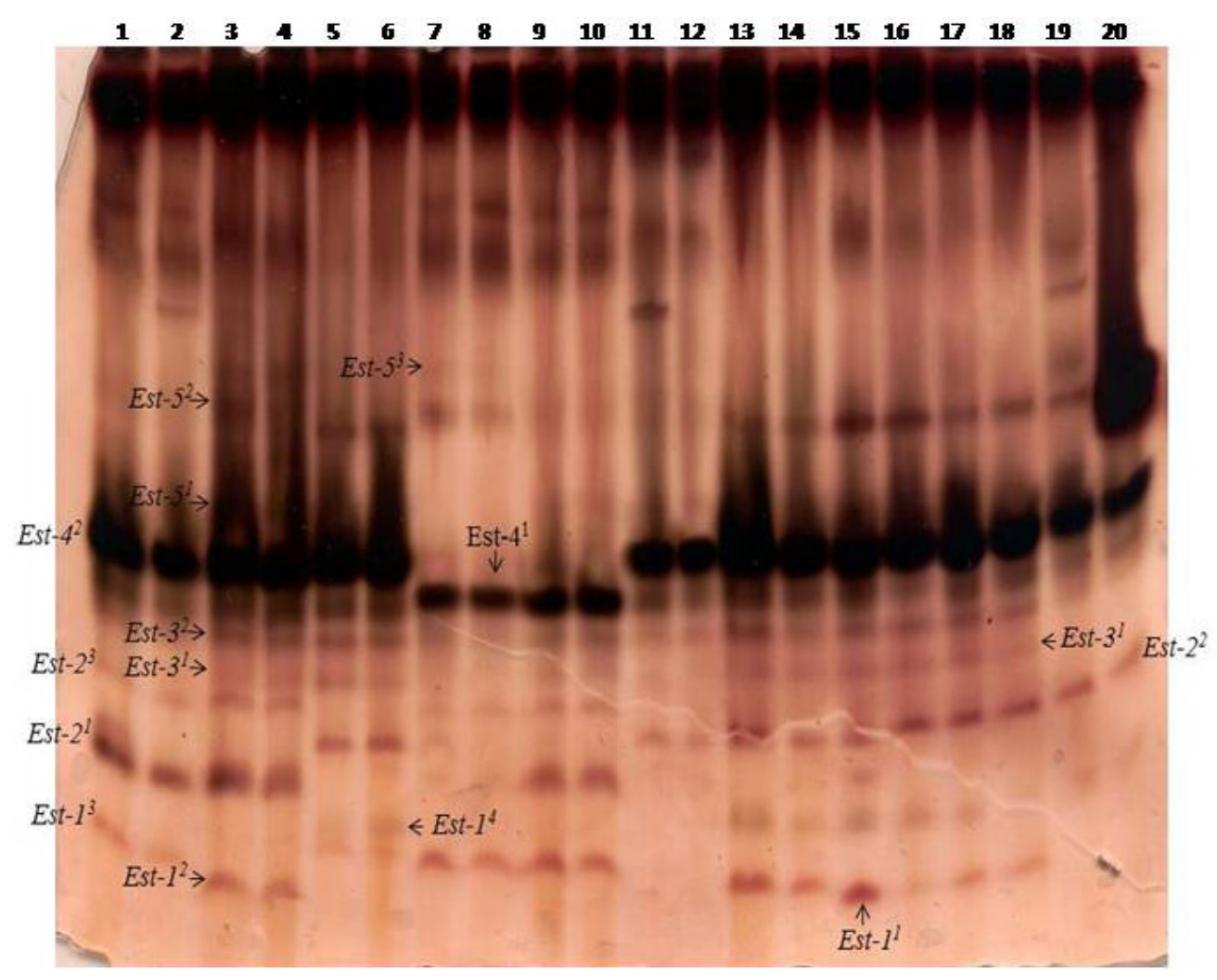

Figure 2. Polymorphism of $\alpha$ - and $\beta$-esterases detected in pepper plants from Capsicum chinense (BAGC 06: samples 1-2; BAGC 07: 3-4; BAGC 23: samples 7-8; BAGC 24: samples 9-10), C. annuum var. glabriusculum (BAGC 11: samples 5-6), C. baccatum var. pendulum (BAGC 26: samples 11-12), C. annuum var. glabriusculum (BAGC 36: samples 13-14; BAGC 59: samples 17-18; BAGC 67: samples 19-20), C. annuum var. annuum (BAGC 40: samples 15-16) accessions, produced from Est-1, Est-2, Est-3, Est-4, and Est-5 loci; the different phenotypes are represented in lanes: lane $1=$ Est- $1^{3 / 3} /$ EsT-2 ${ }^{1 / 3} /$ EsT-3 ${ }^{2 / 2} /$ EsT-4 ${ }^{2 / 2} /$ EsT- $5^{1 / 2} ;$ lane $2=$ EsT- $1^{3 / 3} /$ EsT- $2^{1 / 3} /$ EsT- $3^{2 / 2} /$ EsT-

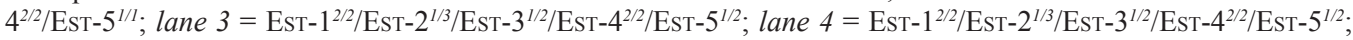

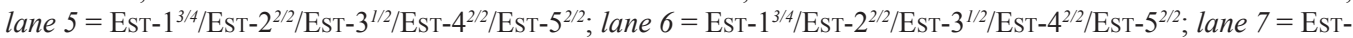

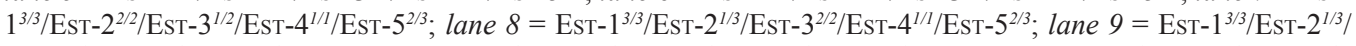
Est- $3^{1 / 2} /$ Est- $4^{1 / 1} /$ Est $^{1 / 2}$; lane $10=$ Est- $1^{3 / 3} /$ Est- $2^{1 / 3} /$ Est- $3^{1 / 2} /$ Est- $4^{1 / 1} /$ Est- $5^{1 / 2} ;$ lane $11=$ Est- $1^{2 / 2} /$ Est- $2^{2 / 2} /$ Est- $3^{1 / 2} /$ EsT-4 $4^{2 / 2} /$ Est- $5^{1 / 2}$; lane $12=$ EsT- $1^{2 / 2} /$ EsT-2 $2^{2 / 2} /$ EsT-3 $3^{1 / 2} /$ EsT-4 ${ }^{2 / 2} /$ Est- $5^{1 / 2} ;$ lane $13=$ EsT- $1^{2 / 4} /$ EsT- $2^{2 / 2} /$ EsT- $3^{1 / 2} /$ EsT- $4^{2 / 2} /$

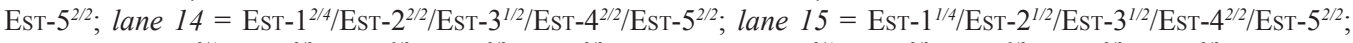

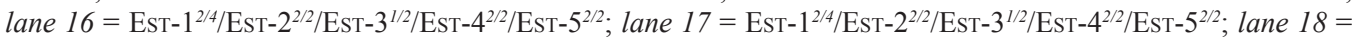

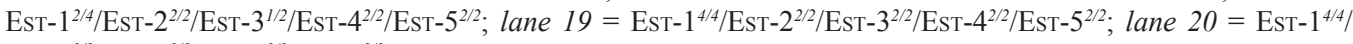

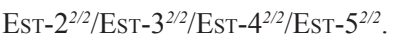


Table 2. Number of alleles $\left(N_{\mathrm{A}}\right)$ per Est-1, Est-2, Est-3, and Est-4 locus, effective number of alleles $\left(N_{\mathrm{E}}\right)$ per polymorphic locus, mean observed $\left(H_{\mathrm{O}}\right)$ and expected heterozygosities $\left(H_{\mathrm{E}}\right)$ in pepper plants from the 10 Capsicum accessions.

\begin{tabular}{|c|c|c|c|c|c|c|}
\hline Accession & $\mathrm{N}$ & $\mathrm{N}_{(\mathrm{pl})}$ & $N_{\mathrm{A}}$ & $N_{\mathrm{E}}$ & $H_{\mathrm{O}}$ & $H_{\mathrm{E}}$ \\
\hline BAGC 06 - C. chinense & 10 & 3 & 1.6 & 1.58 & 0.5600 & 0.2960 \\
\hline BAGC $07-C$. chinense & 10 & 2 & 1.4 & 1.18 & 0.1600 & 0.1280 \\
\hline BAGC 23 - C. chinense & 6 & 4 & 1.8 & 1.39 & 0.3667 & 0.2361 \\
\hline BAGC 24 - C. chinense & 6 & 2 & 1.4 & 1.38 & 0.3667 & 0.1972 \\
\hline Total (C. chinense) & 32 & 5 & 2.4 & 1.82 & 0.3625 & 0.4395 \\
\hline BAGC 11 - C. annuum var. glabriusculum & 10 & 1 & 1.2 & 1.20 & 0.2000 & 0.1000 \\
\hline BAGC 36 - C. annuum var. glabriusculum & 10 & 2 & 1.4 & 1.25 & 0.2200 & 0.1470 \\
\hline BAGC 40 - C. annuum var. annuum & 10 & 2 & 1.4 & 1.40 & 0.4000 & 0.2000 \\
\hline BAGC 59 - C. annuum var. glabriusculum & 9 & 2 & 1.4 & 1.38 & 0.3556 & 0.1951 \\
\hline BAGC 67 - C. annuum var. glabriusculum & 10 & 2 & 1.6 & 1.34 & 0.3200 & 0.2000 \\
\hline Total (C. annuum) & 49 & 4 & 2.4 & 1.71 & 0.2980 & 0.3310 \\
\hline BAGC 26 - C. baccatum pendulum & 10 & 2 & 1.2 & 1.20 & 0.2000 & 0.1000 \\
\hline
\end{tabular}

$\mathrm{N}=$ number of plants analyzed; $\mathrm{N}_{(\mathrm{pl})}=$ number of polymorphic loci.

The estimated $H_{\mathrm{O}}$ and $H_{\mathrm{E}}$ values in the $C$. chinense samples were higher than those detected in the $C$. annuum samples. In the $C$. chinense samples, the highest $H_{\mathrm{O}}$ and $H_{\mathrm{E}}$ values were 0.3625 and 0.4395 , respectively, whereas in the $C$. annuum samples, $H_{\mathrm{O}}$ and $H_{\mathrm{E}}$ values were 0.2980 and 0.3310 , respectively. The highest $H_{\mathrm{O}}(0.5600)$ and $H_{\mathrm{E}}(0.2960)$ values were recorded in the BAGC 06 sample of $C$. chinense. The lowest $H_{\mathrm{O}}$ value $(0.16)$ was recorded in the BAGC 07 sample of $C$. chinense, and the lowest $H_{\mathrm{E}}$ value $(0.10)$ was observed in the BAGC 11 sample of C. annuum var. glabriusculum.

Deviation from Hardy-Weinberg equilibrium was observed for the Est-1, Est-2, and Est-3 loci in the C. annuum samples and for the Est-1, Est-2, Est-3, and Est-4 loci in the C. chinense samples owing to an excess of heterozygous individuals (negative $F$ values). The $F_{\text {IS }}$ value was negative at all Est-1,Est-2, Est-3,Est-4, and Est-5 loci in the C. annuum and C. chinense samples (Table 3). $H_{\mathrm{O}}$ was higher than $H_{\mathrm{E}}$ in all $C$. annuum and C. chinense samples (see Table 2), and therefore, a deficit of homozygous individuals occurred in all pepper accessions of the Capsicum genus analyzed in the present study, including the sole C. baccatum var. pendulum accession.

\begin{tabular}{|c|c|c|c|}
\hline & $F_{\text {IS }}$ & $F_{\mathrm{IT}}$ & $F_{\mathrm{ST}}$ \\
\hline \multicolumn{4}{|c|}{ Capsicum chinense } \\
\hline Est-1 & -0.6259 & -0.2522 & 0.2298 \\
\hline Est -2 & - & 1.0000 & 1.0000 \\
\hline Est-3 & -0.7778 & -0.6667 & 0.0625 \\
\hline Est-4 & -0.0909 & 0.9165 & 0.9235 \\
\hline Est -5 & -0.7872 & -0.1468 & 0.3584 \\
\hline Total & -0.6978 & 0.1631 & 0.5070 \\
\hline \multicolumn{4}{|c|}{ Capsicum аппиит } \\
\hline Est-1 & -0.8828 & 0.0101 & 0.4743 \\
\hline Est-2 & -0.1765 & 0.8805 & 0.8984 \\
\hline Est-3 & -0.8261 & -0.5239 & 0.1655 \\
\hline Est-4 & - & - & 0.0000 \\
\hline Est -5 & -0.1111 & -0.0204 & 0.0816 \\
\hline Total & -0.7750 & 0.0978 & 0.4917 \\
\hline
\end{tabular}


High genetic differentiation levels were detected in the samples of $C$. chinense $\left(F_{\mathrm{ST}}=0.5070\right)$ and $C$. annuum $\left(F_{\mathrm{ST}}=0.4917\right)$ accessions (see Table 3$)$. The $F_{\mathrm{ST}}$ value detected in the $C$. chinense and $C$. annuum samples and $C$. baccatum accessions was 0.6321 , indicating that $63.21 \%$ of the total variance in $\alpha / \beta$-esterase allele frequencies in the three Capsicum species was due to genetic differences among samples. The genetic differentiation between $C$. chinense and $C$. annuum was high $\left(F_{\mathrm{ST}}=0.1867\right)$, indicating that these species are genetically structured $\left(F_{\mathrm{ST}}>0.15\right.$; Wright, 1978$)$ for $\alpha / \beta$-esterase isozymes.

In $C$. chinense samples, Nei's identity $(I)$ values varied between 0.4202 (BAGC 07 and BAGC 23) and 1.0000 (BAGC 23 and BAGC 24; Table 4), showing that the BAGC 23 and BAGC 24 accessions are genetically identical for $\alpha / \beta$-esterase polymorphism (allele frequencies) and indicating a broader genetic base for these samples. In C. annuum samples, $I$ values varied between 0.5727 (BAGC 11 and BAGC 36) and 0.9297 (BAGC 59 and BAGC 67), showing that the BAGC59 and BAGC 67 samples had the highest level of genetic similarity and indicating a relatively lower genetic base in the $C$. annuum samples compared with that in the $C$. chinense samples. The $I$ value between $C$. chinense and $C$. annuum was 0.7147 .

Table 4. Nei's genetic identity (above diagonal) and genetic distance (below diagonal) among accessions of Capsicum chinense (BAGC 06, BAGC 07, BAGC 23, BAGC 24), C. апnиum (BAGC 11, BAGC 36, BAGC 40, BAGC 59, BAGC 67), and C. baccatum (BAGC 26).

\begin{tabular}{|c|c|c|c|c|c|c|c|c|c|c|}
\hline Accession & BAGC 06 & BAGC 07 & BAGC 23 & BAGC 24 & BAGC 11 & BAGC 36 & BAGC 40 & BAGC 59 & BAGC 67 & BAGC 26 \\
\hline BAGC 06 & - & 0.6325 & 0.7017 & 0.6723 & 0.6831 & 0.4317 & 0.4839 & 0.7759 & 0.6801 & 0.5566 \\
\hline BAGC 07 & 0.4580 & - & 0.4202 & 0.4414 & 0.4757 & 0.6823 & 0.8183 & 0.5040 & 0.4669 & 0.6569 \\
\hline BAGC 23 & 0.3543 & 0.8670 & - & 1.0017 & 0.5472 & 0.3000 & 0.3230 & 0.6549 & 0.5211 & 0.1419 \\
\hline BAGC 24 & 0.3970 & 0.8177 & 0.0017 & - & 0.5330 & 0.2922 & 0.3146 & 0.6217 & 0.5034 & 0.1579 \\
\hline BAGC 11 & 0.3812 & 0.7430 & 0.6030 & 0.6292 & - & 0.5727 & 0.6512 & 0.8265 & 0.9235 & 0.3343 \\
\hline BAGC 36 & 0.8400 & 0.3824 & 1.2040 & 1.2302 & 0.5573 & - & 0.8885 & 0.7552 & 0.7205 & 0.5384 \\
\hline BAGC 40 & 0.7260 & 0.2005 & 1.1301 & 1.1563 & 0.4289 & 0.1182 & - & 0.6412 & 0.7045 & 0.5328 \\
\hline BAGC 59 & 0.2538 & 0.6852 & 0.4232 & 0.4753 & 0.1906 & 0.2808 & 0.4444 & - & 0.9297 & 0.3542 \\
\hline BAGC 67 & 0.3855 & 0.7616 & 0.6518 & 0.6863 & 0.0796 & 0.3277 & 0.3502 & 0.0728 & - & 0.3552 \\
\hline BAGC 26 & 0.5860 & 0.4203 & 1.9529 & 1.8456 & 1.0958 & 0.6192 & 0.6296 & 1.0379 & 1.0351 & - \\
\hline
\end{tabular}

Results from cluster analysis using the unweighted pair group method with arithmetic means separated 85 samples into 4 groups (Figure 3). The first group comprised the BAGC 06 (C. chinense) accession and BAGC 11, BAGC 59, and BAGC 67 accessions (C. annuum var. glabriusculum). The second group was composed of the samples BAGC 23 and BAGC 24 (C. chinense). The third group combined the BAGC 07 accession (C. chinense), BAGC 36 accession (C. annuum var. glabriusculum), and BAGC 40 accession (C. annuum var. annuum). The fourth group consisted of the BAGC 26 accession (C. baccatum var. pendulum). Among the 10 accessions of Capsicum species, the highest level of genetic differentiation was observed in the $C$. baccatum var. pendulum sample. I values ranged from 0.1419 (BAGC 26 and BAGC 23) to 1.000 (BAGC 23 and BAGC 24). The geographically distant accessions (BAGC 23 from Teresina, Piauí, and BAGC 24 from Recife, Pernambuco; $1.137 \mathrm{~km}$ apart; see Table 1) showed the highest genetic identity. 


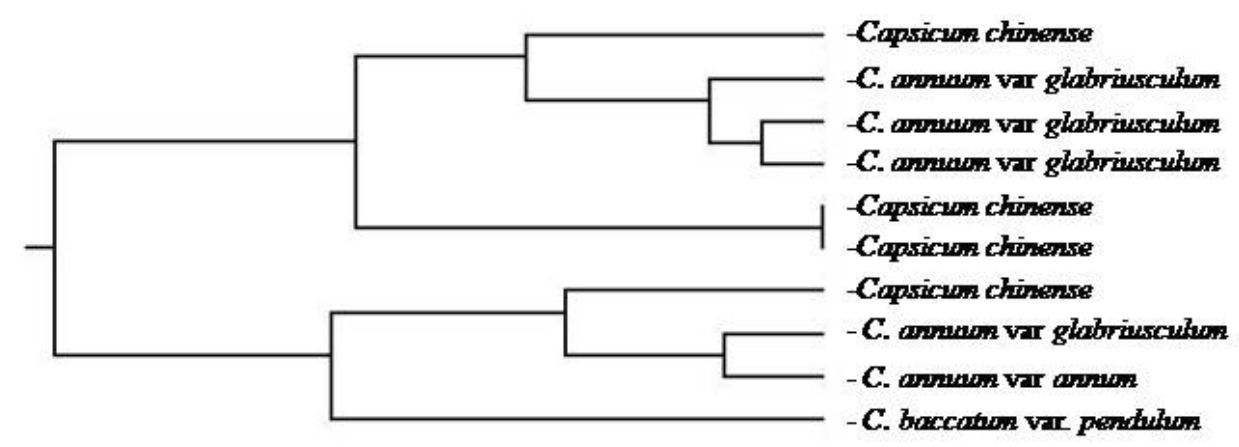

Figure 3. Dendrogram showing relationships of the 10 accessions including Capsicum chinense, C. annuum, and C. baccatum, based on UPGMA cluster analysis of the allele polymorphism at Est-1, Est-2, Est-3, Est-4, and Est-5 loci, by the Jaccard similarity coefficient.

\section{DISCUSSION}

Our results confirmed a previous hypothesis that polymorphisms of the $\alpha / \beta$-esterase isozymes examined using PAGE represent adequate and promising markers for analyzing the genetic differentiation of Capsicum samples maintained in germplasm banks such as the BAGC. Five polymorphic loci for the examined isoesterases were simultaneously evident in the leaves of peppers using only 1 enzymatic system. Because analyses using different enzymatic systems generally incur greater cost and time investments, $\alpha / \beta$-esterase polymorphisms determined using PAGE are promising markers that may be useful in further studies to detect genetic diversity more quickly in other pepper accessions. Esterase isozymes have been described by Barrera et al. (2005) as the most polymorphic isozymes in Capsicum species $(C$. chinense, $C$. frutescens, $C$. annuum, and C. baccatum).

A high level of genetic divergence has been reported in various accessions of Capsicum species maintained at BAGC based on morphological and agronomic markers (color, form, measures of plant parts, flowers, and fruits, number of stems) (Monteiro et al., 2010). The results of $\alpha / \beta$-esterase polymorphism investigation using PAGE in our study indicated that the genetic diversity of the $C$. chinense, $C$. annuum, and $C$. baccatum accessions is also characterized by high mean values for the proportion of polymorphic loci and the observed and expected proportion of heterozygous plants. The proportion of polymorphic loci and $N_{\mathrm{E}}$ were highest in the $C$. chinense samples, and the $H_{\mathrm{O}}$ and $H_{\mathrm{E}}$ proportions of heterozygous plants in this sample were also higher than those estimated in the $C$. annuum and C. baccatum samples. The highest genetic divergence based on morphological and agronomic traits was detected in the $C$. chinense accessions (Monteiro et al., 2010).

The negative $F_{\text {IS }}$ values observed in the $C$. chinense and $C$. annuum samples indicating an excess of heterozygous plants contrasted with the expected moderate to high level of endogamy in Capsicum species. Self-compatibility has been described as the rule in the Capsicum genus (Onus and Pickersgill, 2004). However, the $\alpha / \beta$-esterase phenotype patterns found in our study showed a deficit of homozygous plants or an excess of heterozygous plants. An excess of heterozygous plants $\left(H_{\mathrm{O}}>H_{\mathrm{E}}\right)$ was found in the BAGC 06, BAGC 07, BAGC 23, and BAGC 24 samples of $C$. chinense; in the BAGC 11, BAGC 36, BAGC 40, BAGC 
59, and BAGC 67 samples of C. annuum; and in the BAGC 26 accession of C. baccatum. Increased heterozygosity in the $C$. chinense and $C$. annuum accessions is important because it leads to an increase in the fitness of inbred individuals at loci for which heterozygous specimens have a relative advantage over homozygous specimens (Allendorf and Luikart, 2007). High heterozygosity indicates that a plant population likely includes a substantial amount of adaptive genetic variation, thus allowing it to escape the effects of a control agent. Therefore, polymorphism of $\alpha / \beta$-esterases in the samples of seeds from the germplasm bank revealed that the accessions BAGC 06 of $C$. chinense, BAGC 40 and BAGC 67 of $C$. annuиm var. annuит, and $C$. annuum var. glabriusculum are the samples most indicated for cultivation in various geographical regions (with differential climatic conditions, soil types, and pluvial precipitation). Seeds of BAGC 06, BAGC 40, and BAGC 67 samples showing high heterozygosity are also indicated for selection procedures.

No specific relationship of $\alpha / \beta$-esterase phenotypes and morphological and agronomic traits was investigated in the present study; however, the selection pressure used for morphological and agronomic traits of plant and fruit in the $C$. chinense and $C$. annuum species might also select heterozygous phenotypes in $\alpha / \beta$-esterase loci. Most esterase isozymes in plant tissues have been classified as carboxylesterases (Pereira et al., 2001; Carvalho et al., 2003; Orasmo et al., 2007). The carboxylesterase activity in plants has been correlated with differentiation processes (Gahan et al., 1983; Melati et al., 1996), and different physiological roles have recently been attributed to these compounds. Stuhlfelder et al. (2002) have proposed that carboxylesterases might have a role in plant signaling pathways. The possible substrates for carboxylesterases in plants include esters produced by plants to attract pollinators and deter herbivores (Pichersky and Gershenzon, 2002). The association of the roles of carboxylesterases in plant-pathogen interactions and programmed cell death suppression with the hypersensitive response during pathogen attack has been reviewed by Marshall et al. (2003). Thus, the various physiological roles attributed to carboxylesterases can be used to justify esterase loci as targets in artificial selection processes. In artificially selected plants of Stevia rebaudiana, specific heterozygous phenotypes at Est-2 and Est-4 loci have been observed in taller plants and plants with precocious flowering, respectively (Carvalho et al., 2011). These associations demonstrate that selection procedures for specific characteristics (e.g., height of plants and time of flowering) may lead to a fixation of alleles and $\alpha / \beta$-esterase phenotype patterns in Stevia populations.

The differential allele frequencies and proportions of heterozygous loci found in the pepper accessions indicated that genetic divergence had occurred among the $4 C$. chinense samples $\left(F_{\mathrm{ST}}=0.5070\right)$ and among the 5 C. annuum samples $\left(F_{\mathrm{ST}}=0.4917\right)$. According to Wright (1978), $F_{\mathrm{ST}}>0.25$ indicate a very high interpopulational genetic divergence level. The observed establishment of isolation and structuring mechanisms in the C. chinense and $C$. annuum species can be justified by self-compatibility systems and as a consequence of frequent disturbances such as selection for traits such as multiple resistance genes and for the specific components of quality, such as degree of pungency, flavor, color, and pericarp thickness preferred by consumers; the selection pressure used in conventional Capsicum pepper management has resulted in highly structured populations within $C$. chinense and $C$. annuum species.

The $\alpha / \beta$-esterase phenotype patterns found in $C$. chinense and $C$. annuum also revealed a high divergence level between these species $\left(F_{\mathrm{ST}}=0.1867\right)$, unlike that expected according to previous reports in the literature. $C$. annuum and $C$. chinense (as well as $C$. 
frutescens) have been described as closely related taxa. These 3 species have been included in the $C$. апnиum complex, whereas poorly developed crossing barriers and great similarities with respect to morphology, karyotype features, isozymes, and DNA sequences suggest that they could be conspecific (Pickersgill, 1988, 1991; Park et al., 2000; Walsh and Hoot, 2001). Studies based on enzyme electrophoresis have indicated that this $C$. annuиm complex forms an allozymically indistinguishable group of populations (McLeod et al., 1983; Barrera et al., 2005). However, in such studies, the data from zymograms have been entered as a matrix of presence/absence of isozymes for each enzyme system. The isozymes analyzed were treated as dominant markers, whereas the allele frequencies and homozygous and heterozygous plants were not detected. The isozymes were not useful for analyzing the genetic structure of the Capsicum plant populations. Conversely, the gene diversity estimates from 186 accessions of Capsicum from Mexico ( 76 alleles representing 20 genetic loci coding for 9 enzyme systems) suggested significant genetic differentiation, mainly among populations from different geographical regions (Loaiza-Figueroa et al., 1989). The BAGC accessions most geographically distant were not the most genetically divergent; however, significant genetic differentiation was observed among the $C$. chinense and $C$. annuum samples in our study, similar to that described by Loaiza-Figueroa et al. (1989) through isozyme analysis.

The level of genetic divergence in the $C$. chinense and $C$. annuum accessions revealed through $I$ values (0.4202-1.0000 and 0.5727-0.9297, respectively) indicated a broader genetic base for these Capsicum species. In practical terms, this result represents an important finding for both species because the most divergent genotypes may be used to produce superior hybrids in breeding programs based on the assumption that the highest molecular dissimilarity in the genotypes may represent greater heterozygosity and consequently a greater probability of generating superior hybrids (Serafiniet al., 2001).

The $I$ value between $C$. chinense and $C$. annuum was 0.7147 . This low identity value may also be explained as a consequence of the different origins of the examined $C$. chinense and $C$. annuum samples. The cultivation of $C$. annuum has been postulated to have occurred first in Mexico, which is the major center of diversity for this species and in which archeological remains from approximately 7000 B.C. have been uncovered (Pickersgill, 1969). Support for this hypothesis has been found in cytogenetic data published by Pickersgill (1971). Patterns of genetic variation obtained through enzyme electrophoretic studies have also suggested a primary center of domestication in eastern Mexico and a second center in western Mexico (Loaiza-Figueroa et al., 1989). With respect to C. chinense, domestication reportedly began in the lowland Amazon basin, which is the area of greatest diversity (International Board for Plant Genetic Resources - IBPGR, 1983).

Our results enable us to suggest the use of $\alpha / \beta$-esterase isozymes determined using PAGE for the analysis of the genetic structure and diversity among and within Capsicum species. The esterase analysis carried out in the current study showed that high genetic diversity exists within $C$. chinense and $C$. annuum samples and among 3 Capsicum species. Understanding the genetic structure of these pepper accessions is important and, in the near future, may lead to new management strategies for the culture and maintenance of various cultivars. In fact, knowledge of genetic diversity may be important for guiding management practices and for the development of more effective cultivation methods in these species. For example, future cultivation or control of pests in peppers of the Capsicum species showing a higher level of mean heterozygosity may require different types and concentrations of nutrients or 
pesticides. Additionally, producing peppers from C. chinense and C. annuum accessions exhibiting high heterozygosity may be the goal of continuous medium- and long-term selection to generate inbred lines and for the future production of new cultivars in breeding programs. The $\alpha / \beta$-esterase phenotype patterns obtained herein may be applied to the monitoring of genetic stability in selected populations for specific traits of interest.

\section{REFERENCES}

Allendorf FW and Luikart G (2007). Conservation and the Genetics of Populations. Edition Blackwell Publishing, Maden. Barrera LQ, Garcia MC, Giraldo MC and Melgarejo LM (2005). Caracterizacíon por isoenzimas de accesiones de Capsicum pertenecientes a la colección Amazonica colombiana. Rev. Colomb. Biotecnol. 2: 59-65.

Bosland PW and Votava EJ (2000). Peppers: Vegetable and Species Capsicum. 12th edn. CABI Publishing, Oxon.

Buso GSC, Lourenço RT, Bianchetti LB, Lins TCL, et al. (2001). Espécies Silvestres do Gênero Capsicum Coletadas na Mata Atlântica Brasileira e sua Relação Genética com Espécies Cultivadas de Pimenta: Uma Primeira Abordagem Genética Utilizando Marcadores Moleculares. Embrapa Recursos Genéticos e Biotecnologia, Brasília.

Carvalho VM, Marques RM, Lapenta AS and Machado MFPS (2003). Functional classification of esterases from leaves of Aspidosperma polyneuron M. Arg. (Apocynaceae). Genet. Mol. Biol. 26: 195-198.

Carvalho VM, Marochio CA, Mangolin CA and Machado MFPS (2011). The use of esterase polymorphism for analysis of the genetic diversity and structure of stevia (Stevia rebaudiana Bert. Bertoni) populations. Biochem. Syst. Ecol. 39: 594-599.

Frigo MJ, Mangolin CA, Oliveira RS Jr and Machado MFPS (2009). Esterase polymorphism for analysis of genetic diversity and structure of wild poinsettia (Euphorbia heterophylla) populations. Weed Sci. 57: 54-60.

Gahan PB, Rana MA and Phillips R (1983). Activation of carboxylesterases in root cortical parenchymal cells of Pisum sativum during xylem induction in vitro. Cell Biochem. Funct. 1: 109-111.

International Board for Plant Genetic Resources (IBPGR) (1983). Genetic Resources of Capsicum, a Global Plan of Action. IBPGR Executive Secretariat, Rome.

Kirschbaum-Titze P, Hiepler C, Mueller-Seitz E and Petz M (2002). Pungency in paprika (Capsicum annuum). 1. Decrease of capsaicinoid content following cellular disruption. J. Agric. Food Chem. 50: 1260-1263.

Loaiza-Figueroa F, Ritland K, Labor de Cancino JA and Tanksley SD (1989). Patterns of genetic variation of the genus Capsicum (Solanaceae) in Mexico. Plant Syst. Evol. 165: 159-188.

Marshall SD, Putterill JJ, Plummer KM and Newcomb RD (2003). The carboxylesterase gene family from Arabidopsis thaliana. J. Mol. Evol. 57: 487-500.

McLeod MJ, Guttman SI, Eshbaugh WH and Rayle RE (1983). An electrophoretic study of evolution in Capsicum (Solanaceae). Evolution 37: 562-574.

Melati MR, Scialabba A and Bellani ML (1996). Carboxylestrase activity in the carrot seed and seedling. Eur. J. Histochem. 40: 159-166.

Monteiro ER, Bastos EM, Lopes ACA, Gomes RLF, et al. (2010). Diversidade genética entre acessos de espécies cultivadas de pimentas. Cienc. Rural 40: 288-283.

Moscone EA, Scaldaferro MA, Grabiele M, Cecchini NM, et al. (2007). The evolution of Chili Peppers (Capsicum Solanaceae): a cytogenetic perspective. Acta Hortic. 745: 137-170.

Nei M (1978). Estimation of average heterozygosity and genetic distance from a small number of individuals. Genetics 89: 583-590.

Onus AN and Pickersgill B (2000). A study of selected isozymes in Capsicum baccatum, Capsicum eximium, Capsicum cardenasii and two interespecific $\mathrm{F}_{1}$ hybrids in Capsicum species. Turk. J. Bot. 24: 311-318.

Orasmo GR, Oliveira-Collet SA, Lapenta AS and de Fatima PSM (2007). Biochemical and genetic polymorphisms for carboxylesterase and acetylesterase in grape clones of Vitis vinifera L. (Vitaceae) cultivars. Biochem. Genet. 45: 663-670.

Park YK, Park KC, Park CH and Kim NS (2000). Chromosomal localization and sequence variation of 5S rRNA gene in five Capsicum species. Mol. Cells 10: 18-24.

Pereira AJ, Lapenta AS, Vidigal-Filho PS and Machado MF (2001). Differential esterase expression in leaves of Manihot esculenta Crantz infected with Xanthomonas axonopodis pv. manihotis. Biochem. Genet. 39: 289-296.

Pichersky E and Gershenzon J (2002). The formation and function of plant volatiles: perfumes for pollinator attraction and defense. Curr. Opin. Plant Biol. 5: 237-243.

Pickersgill B (1969). The Domestication of Chili Peppers. In: The Domestication and Exploitation of Plants and Animals 
(Ucko PJ and Dimbleby GW, eds.). Duckworth, London, 443-450.

Pickersgill B (1971). Relationships between weedy and cultivated forms in some species of chili peppers (genus Capsicum). Evolution 25: 683-691.

Pickersgill B (1988). The genus Capsicum: a multidisciplinary approach to the taxonomy of cultivated and wild plants. Biol. Zentralbl. 107: 381-389.

Pickersgill B (1991). Cytogenetics and Evolution of Capsicum L. In: Chromosome Engineering in Plants: Genetics, Breeding, Evolution, Part B (Tsuchiya T and Gupta PK, eds.). Elsevier, Amsterdam, 139-160.

Pickersgill B (1997). Genetic resources and breeding of Capsicum spp. Euphytica 96: 129-133.

Reifschneider FJB (2000). Capsicum: Pimentas e Pimentões do Brasil. Embrapa Hortaliças, Brasília.

Robin C, Russell RJ, Medveczky KM and Oakeshott JG (1996). Duplication and divergence of the genes of the $\alpha$-esterase cluster of Drosophila melanogaster. J. Mol. Evol. 43: 241-252.

Serafini LA, Fungaro MHP and Vieira MLC (2001). Marcadores Moleculares. In: Biotecnologia na Agricultura e na Agroindústria (Serafini LA, Barros MN and Azevedo JL, eds.). Livraria e Editora Agropecuária Ltda., Guaíba, 1531999.

Stuhlfelder C, Lottspeich F and Mueller MJ (2002). Purification and partial amino acid sequences of an esterase from tomato. Phytochemistry 60: 233-240.

Votava EJ, Baral JB and Bosland PW (2005). Genetic diversity of Chile (Capsicum annuum var. annuum L.) landraces from northern New Mexico, Colorado, and Mexico. Econ. Bot. 59: 8-17.

Walsh BM and Hoot SB (2001). Phylogenetic relationships of Capsicum (Solanaceae) using DNA sequences from two noncoding regions: the chloroplast atpB-rbcL spacer region and nuclear waxy introns. Int. J. Plant Sci. 162: 14091418.

Wright S (1965). The interpretation of population structure by F-statistics with special regard to systems of mating. Evolution 19: 395-420.

Wright S (1978). Evolution and the Genetics of Populations 4. Variability Within and Among Natural Populations. University of Chicago Press, Chicago.

Yeh FC, Yang R and Boyle T (1999). Popgene Version 1.32: Microsoft Windows-Based Freeware for Population Genetic Analysis. Centre for International Forestry Research, University of Alberta, Calgary. 